\title{
An overview and review of testing methods for the verification and validation of ADAS, active safety systems, and autonomous driving
}

\begin{abstract}
The number of advanced driver assistance systems has increased dramatically in recent years. This led to a need for the development of testing methods to prove the quality and reliability of such systems. This publication presents an overview of the testing methods used in the automotive industry for the verification and validation of advanced driver assistance systems (ADAS), active safety, and autonomous driving systems. The first part presents the approach to X-in-the-loop testing such as model, software, hardware, etc., presenting the most interesting implementations. Then it discusses testing in proven areas like road traffic, artificial cities, and test tracks. The last part presents validation in the laboratory using both invasive and non-invasive methods based on virtual test drives, sensor stimulators and chassis dynamometers. Moreover, we identified the most promising approaches for the efficient verification and validation of ADAS, active safety and autonomous driving systems. Finally, we address some gaps in the research which require further investigation.
\end{abstract}

Key words: ADAS validation, active safety systems verification, autonomous driving, testing methods, in the loop testing

\section{INTRODUCTION}

Modern cars increasingly have more advanced active safety systems. Currently, there are no fully autonomous cars, yet some of them significantly reduce the need for driver interaction. Currently, autonomous driving systems are developed based on SIL (Software in The Loop) and HIL (Hardware in The Loop) methods, while tests are performed manually on test tracks and/or on public roads by test drivers. These methods are far from perfect due to the inability to create many test cases, the required human presence in the car during tests, and above all, the problem of repeated reconstruction of identical road conditions. Such conditions can only be reproduced in the laboratory by using specialized tools. The cre- ation of tests in the laboratory would allow for cars to be tested in identical conditions. This, in turn, would allow cars to be compared to each other and, above all, certified based on defined procedures and test standards. There are many publications that show different approaches to testing active safety and autonomous driving systems, ranging from road traffic tests to laboratory tests. Currently, tests in the laboratory (commonly called Vehicle-in-the-loop) mainly focus on the tests of a single system, such as radar or lidar. For some time, engineers have been trying to create a test system that would be able to test several systems simultaneously, but unfortunately such a system is still not available. Therefore, the following question arises - Is it possible to create a test system that will be able to simulate the external world in the laboratory 
so that driver assistance or autonomous driving systems can be tested comprehensively? This paper presents a review of this topic and attempts to specify the missing technologies.

\section{X-IN-THE-LOOP TESTING}

$\mathrm{X}$-in-the-loop is a naming convention, where $\mathrm{X}$ denotes an object under test. As testing is not a one-off activity but a cyclic one, it is called loop testing. In the automotive industry, you can test many things in the loop, with the most popular applications presented here. These approaches are ordered in accordance with the chronology within the timeline of the tested system development as shown in Figure 1. However, it should be remembered that not all steps must be performed, because it depends on the specifics and complexity of the system. There is also some difference between verification and validation. Verification is intended to check whether the system meets predefined requirements, standards, and norms, while validation provides evidence that the system performs its role in a real application, in the target environment [1].

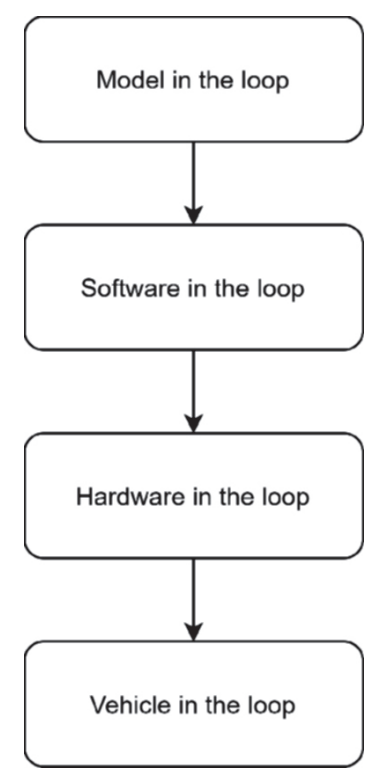

Fig. 1. Steps in a System Development

\subsection{Model-in-the-loop (MIL)}

The first step in the production of the system is a model in the loop (MIL), where the designed system is in the form of a model created in a modelling tool, e.g., in MATLAB-Simulink. By means of generic components a general, high-level model of the system's operation is created. As a result, we can design the system without entering the implementation details, which depend on the programming language. In addition, having such a model, we can automatically generate code in a specific language using for example, Simulink Coder or Target Link [2], thanks to which we avoid manual code writing [3] as shown in Figure 2. Testing the model involves providing a set of simulated signals to the model and checking its response.

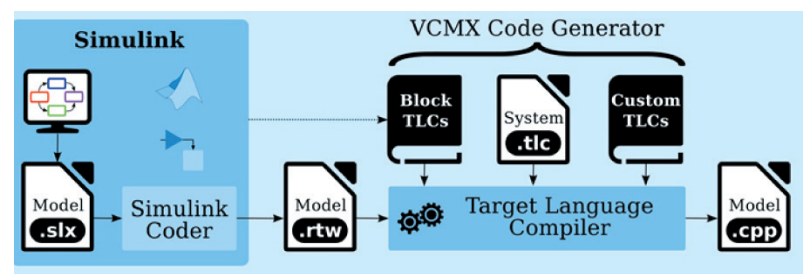

Fig. 2. Code generation process of Simulink [2]

\subsection{Software-in-the-loop (SIL)}

The next step is software in the loop (SIL), where our subject of testing is no longer the block model, but code in a specific programming language, e.g., $\mathrm{C}++$. We can test this code by providing appropriate artificial or acquired data to its inputs. Thanks to that, we can verify the correctness of the implemented algorithms in a specific programming language in abstraction from dedicated hardware, e.g., with code running on a PC computer [4]. Such an approach brings with it some risks. First of all, if the computer program is compiled with different compiler, so the machine code may be slightly different to a machine code compiled with dedicated compiler. During execution, such programs can behave differently, so there is no $100 \%$ certainty that this program will behave exactly the same on the final hardware.

\subsection{Hardware-in-the-loop (HIL)}

After finishing of SIL tests, there are performed hardware in the loop tests, where the software is already tested on dedicated hardware, but not yet in a dedicated environment. This means that all other cooperating electronic devices must be simulated, so from the perspective of the device under test, there is no difference whether it is in a real or simulated 
environment. This is probably the most common type of testing in the automotive industry, because usually the manufacturer of the designed device is responsible for only one device and has no access to other cooperating devices. The HIL example can be an ECU, which is responsible for recognizing lines on the road, is tested in a simulated environment [5] oraz HIL as shown in Figure 3. The main drawback is that the device is not tested in real environment with other real ECUs, with real power supplies etc. Therefore, there is a chance that the device will not work correctly in a real environment.

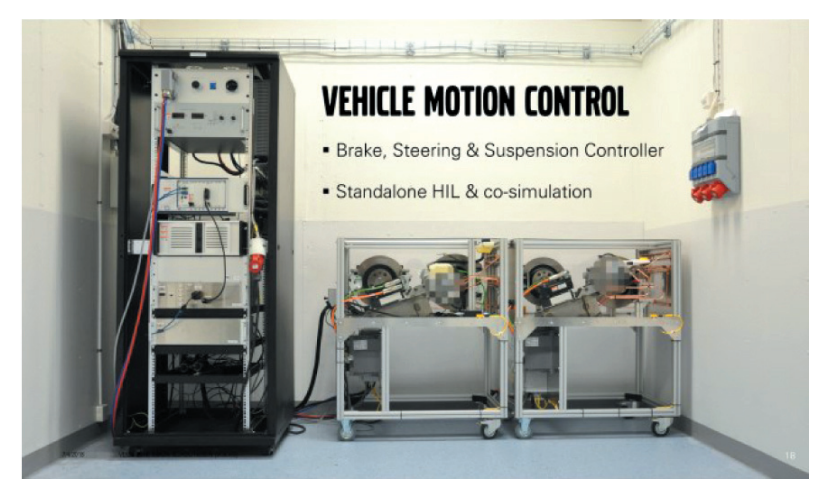

Fig. 3. This vehicle motion control HIL system tests braking, steering, and suspension controllers. The system can act as a stand-alone HIL test setup or be run in co-simulation with the Dynamic Driving Simulator [6]

\subsection{Vehicle-in-the-loop (VIL)}

The last step of testing is testing a complete car in a laboratory. Such a car is usually set on a chassis dynamometer, which, by applying the right torque to the wheels, simulates, for example, driving on a hill or other traffic resistance. In addition, car sensors are stimulated using various types of devices that work with driving simulators that are responsible for virtual test drives. In this testing method, it is often possible to meet the terms of testing in the open and closed loop, which are worth introducing here.

\subsubsection{Open loop testing}

Open loop testing occurs when the system under test is stimulated from the outside, but its response is not fed back to the simulator. For this reason, we do not have information about the car's reaction in the simulation. An example of testing in an open loop can be an ECU which is responsible for car detection [7]. The first step was recording the video during a real test drive, then an identical test drive was performed in the simulator, and at the end the cars were separated from the virtual drive and added to the recorded movie as shown in Figure 4. The test consisted of sending this video with added cars to the camera and analysing whether the ECU detected other vehicles. Under such conditions, it is not possible to test how the active safety system works because a recorded video cannot react to the system's behaviour.

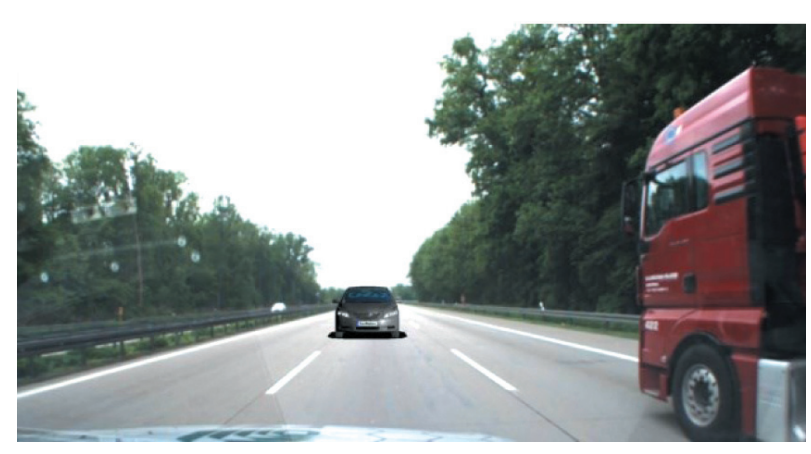

Fig. 4. Real test drives augmented with virtual car [7]

\subsubsection{Closed loop testing}

Closed loop testing occurs when the response of the tested system is fed back into the simulator. Thanks to this, the reaction of the car is visible in the simulation. Closed loop testing provides an interactive simulated environment to the system under test, but it is much more demanding for a test system than the open loop method.

\subsection{Other methods}

In addition to the general methods described above, there are a number of other, more specific ones, such as Engine-in-the-loop (EIL) or Battery-in-the-loop (BIL), where the engine [8] or the batteries are tested [9]. Sometimes, humans are also tested to evaluate likely behaviour in specific situations or cooperation with safety systems.

\subsubsection{Driver-in-the-loop (DIL)}

In addition to testing the manufactured system, one can also test driver behaviour while driving a car (Fig. 5). 
Thanks to this, one can obtain information about the behaviour of the driver in certain situations and thus better design the system in the car. Moreover, it is also possible to acquire information about cooperation, e.g., with active safety systems to validate if additional safety systems improve or worse the driver's reaction. An example would be testing the reaction time of the driver during braking with cooperation with intelligent lamps [10]. Of course, the driver can be tested in different environment. The less real conditions are when the driver's behaviour is tested during completely virtual test e.g., by using VR goggles. Even better is to test the driver in a real vehicle, but in a simulated environment. The most accurate is to test driver's behaviour in a real vehicle during a real test drive. Such approach gives the most precise results and certainty that the designed safety system improves or worse the driver's safety.

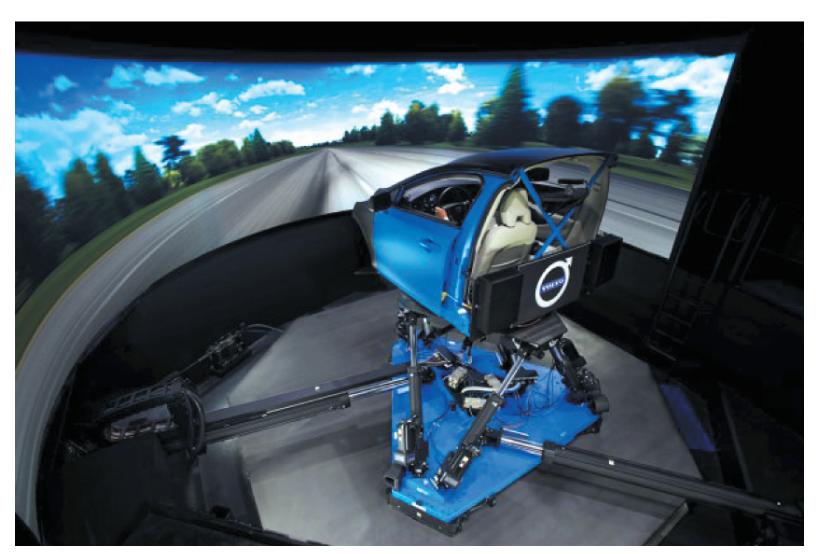

Fig. 5. Volvo Dynamic Driving Simulator [6]

\subsubsection{Pedestrian-in-the-loop (PIL)}

Pedestrian behaviour can be tested similarly to driver behaviour. By observing the pedestrians in different situations, one can assess how they interact with the car. An interesting example was given in the publication [11], where the behaviour and movement of several people is observed during a dangerous event with an autonomous car. The people have VR goggles on their heads, in which a virtual test drive is displayed. Similar tests were carried out with one passer-by, whose task was to enter a pedestrian crossing at the right moment to check whether the emergency braking algorithm of the vehicle worked properly [12] as shown in Figures 6 and 7.

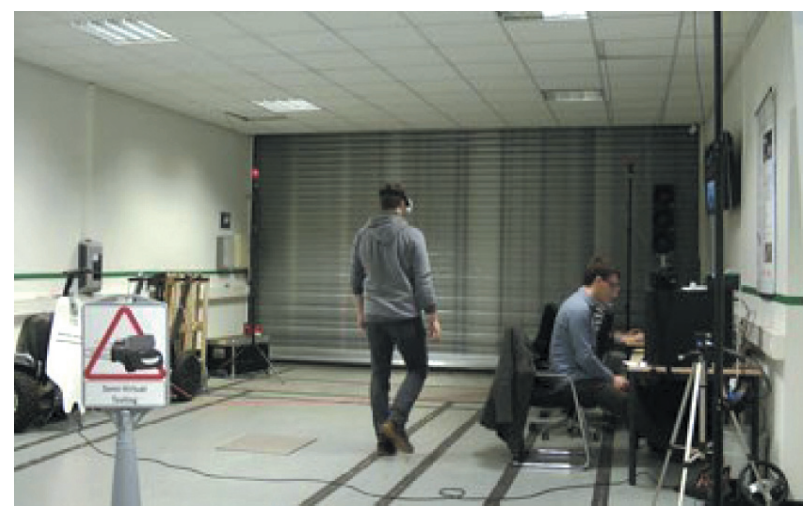

Fig. 6. Pedestrian with VR goggles [12]

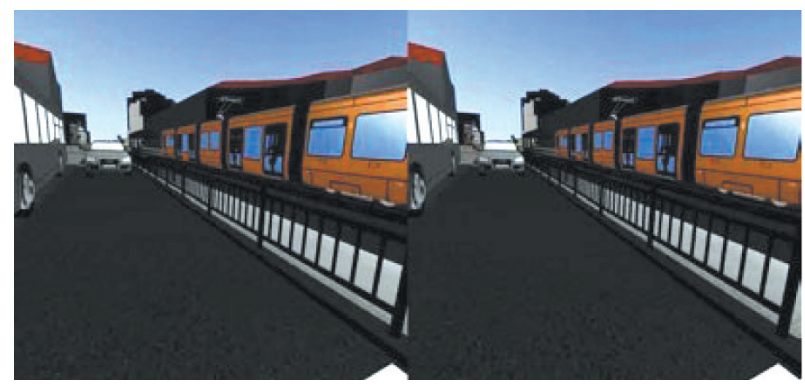

Fig. 7. Image seen by pedestrian [12]

\section{VEHICLE TESTING METHODS}

So far, the X-in-the-loop approach was presented. In the final step, vehicle tests are performed in a real environment. There are mainly three types of proving ground tests - road traffic, artificial cities, and test tracks.

\subsection{Road traffic testing}

Test drives in road traffic are the most popular methods of testing autonomous driving and active safety systems. In addition to the obvious advantage of driving in a natural, targeted environment, it has many disadvantages. The first drawback is the low repeatability of test conditions, which are basically non-reproducible. Secondly, the car must be fully functional, so these tests must be carried out at the end of product development, extending the development time. Test drives can cause danger to other users and the driver himself, so it is required to avoid testing immature systems. Also, testing on public roads is inconvenient and time-consuming, as every modification of hardware or software requires returning to the company's site. Unfortunately, more and more countries have prohibited the testing of autonomous cars 
in road traffic due to accidents, something which is driving the development of novel alternative testing methods. An example of test performed in road traffic environment is shown in Figure 8.

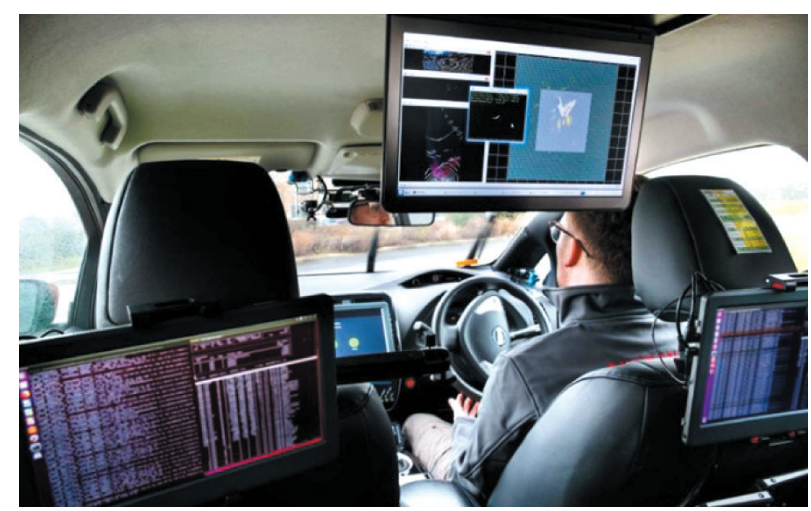

Fig. 8. Road traffic test [13]

\subsection{Closed area testing}

In addition to road traffic tests, tests are carried out in closed areas specially adapted for testing.

\subsubsection{Artificial cities}

An alternative can be testing cars under artificial conditions, such as in an artificial city that has been built specifically for testing purposes. Such cities exist, among others, in South Korea - K-city [14] or in the USA - Mcity [15]. The map of such city is shown in Figure 9.

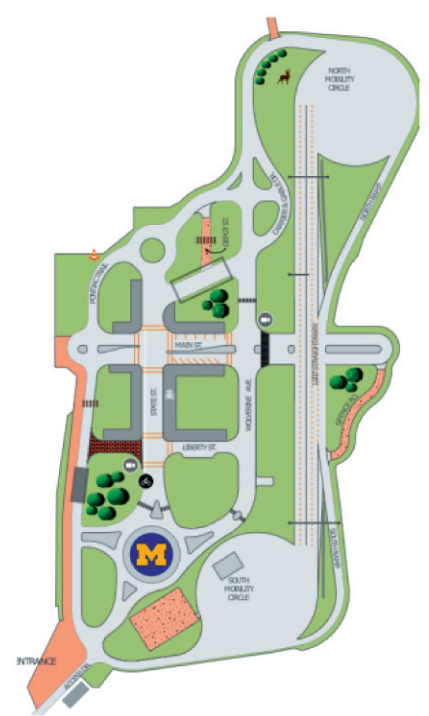

Fig. 9. Mcity map [16]

For example, Mcity consists of 40 building facades, from a tunnel, a bridge, a four-lane highway, and even mechanical pedestrians who can enter the pedestrian crossing. In addition, it is equipped with standard road markings and traffic lights [15]. A part of Mcity is shown in Figure 10. Testing in such conditions has many advantages, such as the ability to test in conditions that do not threaten other road users. Moreover, all test conditions are reproducible except for weather conditions. An important advantage is the possibility of any configuration of the environment, for example by changing signs or traffic lights. Despite all these advantages, there are still some drawbacks in this method, including a degree of danger to the driver during the tests. Furthermore, building such a city is very expensive and time consuming, and the car itself still must be fully functional.

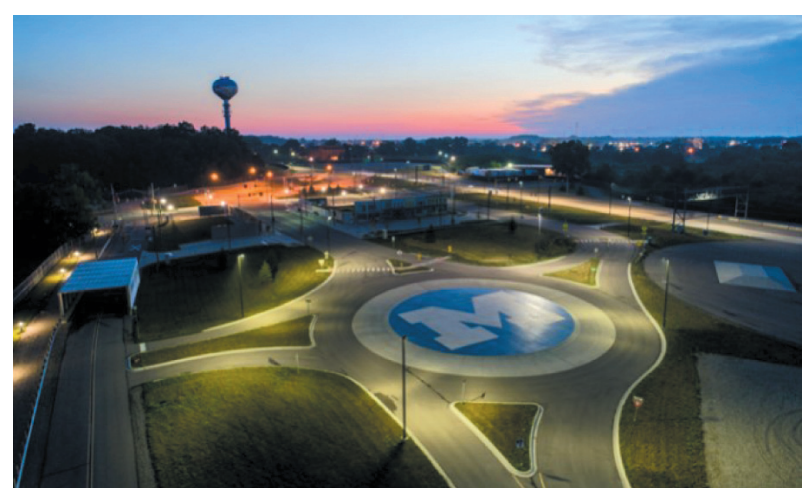

Fig. 10. Mcity test facility [16]

\subsubsection{Test tracks}

A cheaper alternative is testing on test tracks or all kinds of empty squares. Usually, on the track there are individual obstacles that allow validating a given system of active safety, e.g., emergency braking. An example of test performed on empty square is shown in Figure 11. This kind of testing is probably the most popular because it is the cheapest and fastest in implementation. It is often the initial phase before testing in road traffic.

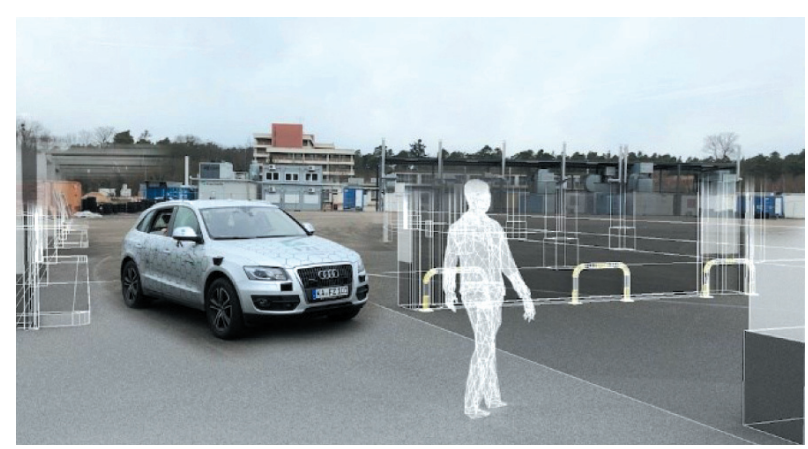

Fig. 11. Car is being tested on test track under the influence of a mixed reality environment [17] 


\subsubsection{Semi-virtual tests}

Also, it is a common practice to combine a virtual test drive with a real one. At the beginning, the entire real track is mapped into the simulation. Then, a test car equipped with a high-accuracy Differential GPS (DGPS) sends its location to the simulator, which sends back the data in the appropriate format, e.g., for radar. This information is sent directly to the ECU of the radar, excluding the radar sensor itself, and the active safety system is triggered [18, 19]. Thanks to this the test is performed on a real track where there are no road users, while from the perspective of the car, it is driving along the same track simultaneously with other cars. Also, often in such mixed rides the driver is equipped with goggles, in which the reality is augmented by elements generated by the simulator. Thanks to this approach, the driver avoids motion sickness and is aware of the resulting car maneuvers.

Another approach to semi-virtual tests is to drive on an empty track where the driver is equipped with VR goggles displaying the completely virtual test drive as shown in Figure 12. The advantage of this approach is that the driver experiences all of the relevant forces while conducting a virtual test drive [20].

The semi-virtual tests can also be applied during the testing of a crossover management controller. The controller assigns the time in which each car could pass the intersection. As the tested car was not equipped with actuation systems that would be able to control the car, the car was run by a driver who performed the controller's commands sent to a dedicated smartphone application [21].

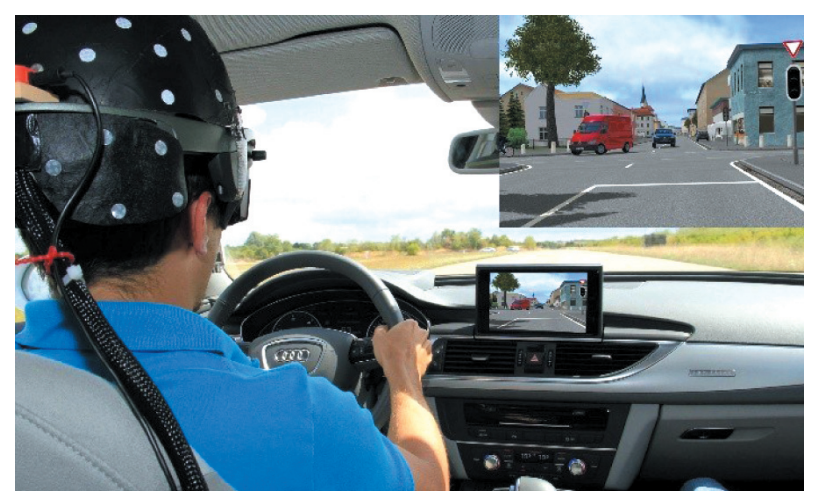

Fig. 12. Real test drives augmented with virtual car [20]
Semi-virtual tests often require the presence of a driver in the car, which can be dangerous, especially when the vehicle is a prototype. This risk can be avoided by replacing the driver by actuators which can be controlled wirelessly.

\subsection{Laboratory tests}

When it comes to Vehicle-in-the loop testing where the car is tested in laboratory conditions, the problem is simulating the outside world and stimulating the sensors, so that you can test the functionality. This can be done in several ways presented below.

\subsubsection{Invasive methods}

In invasive methods, one must interfere with the construction of the car. The most invasive method is to disconnect the ECU and inject the relevant data directly to the communication bus [22]. For example, radar ECU can be disconnected, and communication bus is fed with frames containing specific values. Then we are able to observe the vehicle reaction to these data. This method is inconvenient and basically not used, because it requires a significant interference into the construction of the car and deep knowledge of transmitted data structures. This effectively limits the use of this method to OEMs only.

A less invasive way is to leave the ECU connected, but disconnect only the sensor itself from the ECU and after that send electrical signals to the ECU in accordance with the sensor datasheet. As it is much easier to obtain the documentation of the sensor than a documentation of car internal communication systems, this method is already sporadically used.

\subsubsection{Non-Invasive methods}

There are also a few methods that do not disturb the construction of a car. The first method is to move physical objects in front of the car to trigger the tested systems. For example, a large hall can be used, and the car can be placed on a chassis dynamometer, while traffic is carried out using fake cars that are moved relative to the tested car [23] as shown in Figure 13. This solution has many disadvantages. It is very expensive because one must build cars or other 
objects that will interact with the tested car. Also, a large room of about $100 \mathrm{~m}$ in length is necessary [23] and finally, such an enterprise is very dangerous to the surroundings.

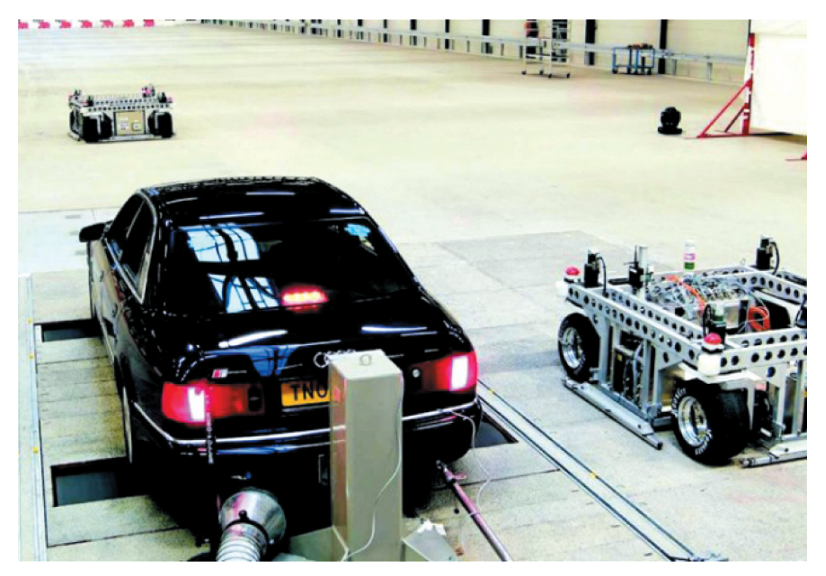

Fig. 13. Tested vehicle on the dyno with fake cars [23]

A very expensive solution, but arguably the most flexible, is to stimulate car sensors using dedicated devices. This approach is commonly used when testing active safety systems or ADAS. Such a test system consists of several components. It comprises a driving simulator which is a computer program that performs virtual test drives. In such a tool, one can also create unique roads, determine the number of lanes, level of road gradient, insert trees and other traffic participants such as cars, pedestrians, etc. [24]. The car is mapped in a simulator and is referred to in the literature as an EGO vehicle. This simulator has built in sensor models such as radar, lidar, etc. Thanks to this, it provides signals in a format dedicated for tested system, which are then sent wirelessly to the corresponding sensors in the car using specialized equipment. The tested car reacts to the received data by changing the trajectories of movement or by activating some active safety system. This reaction is measured, and is sent back to the simulator as physical values. Based on this data, our EGO vehicle reflects the behaviour of the tested vehicle. An example of this is the "Driving Cube" project [25, 26], in which the car was placed on a chassis dynamometer, while special devices were set at the front of the car to wirelessly stimulate the sensors as shown in Figure 14. A special computer program performed the virtual test drive and generated data for stimulators and for the chassis dynamometer.

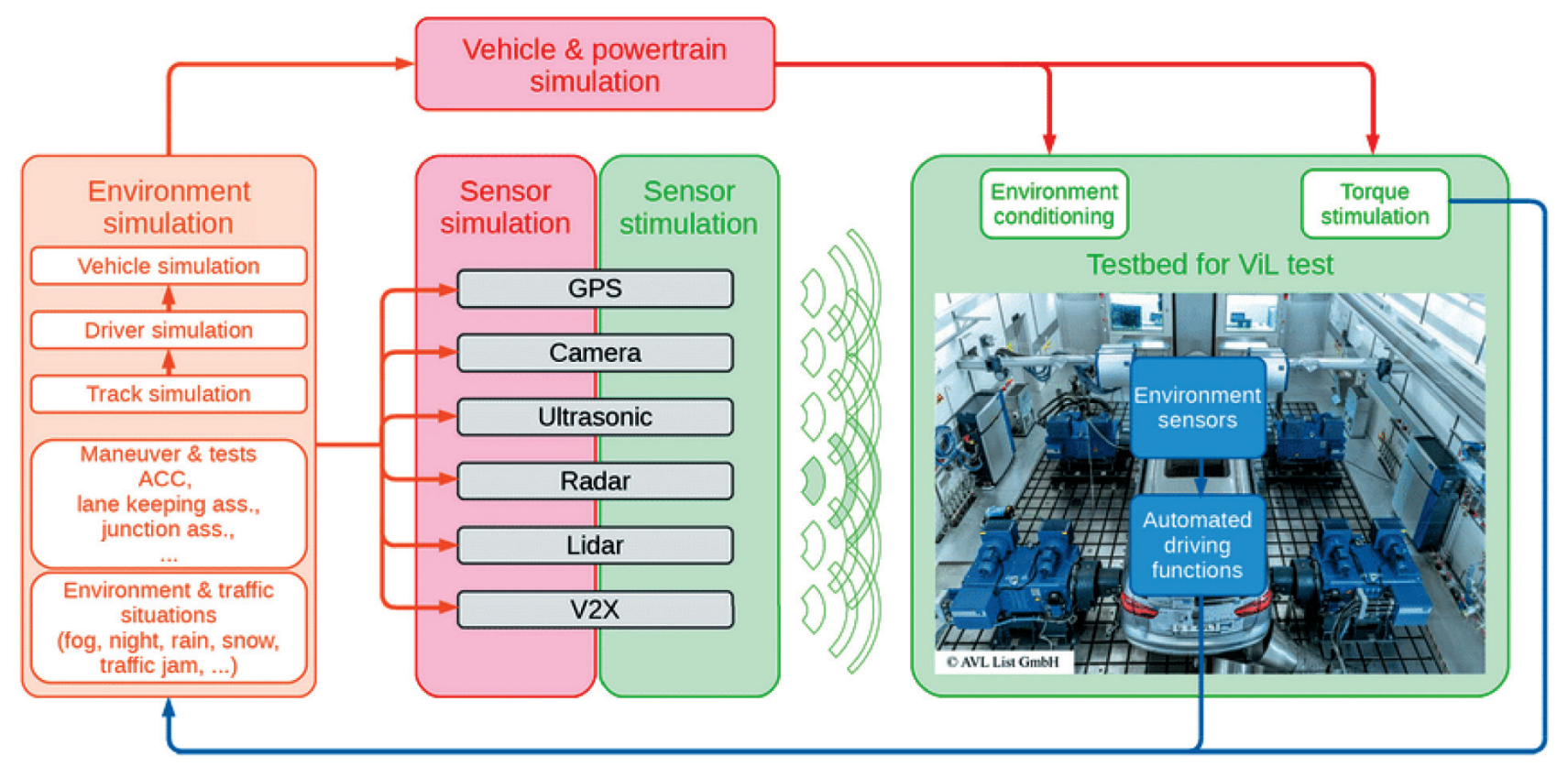

Fig. 14. Driving-Cube test bench for holistic testing of automated driving [27]

\section{CONCLUSIONS}

There are several ways to verify and validate ADAS and autonomous driving, from road traffic to testing in the laboratory. Currently, laboratory testing is widely used and constantly developed. However, due to the associated costs, only the largest car companies can afford it. Unfortunately, there is no 
VIL test system that would be able to stimulate all of the systems used for autonomous driving. From the reviews performed we found that there exist systems that test a single system. Driving Cube is such an example where the radar and camera are tested simultaneously. Such a system primarily lacks the lidar and GPS stimulator, which are crucial systems for autonomous driving. Despite the constantly developing methods, to achieve the above-described goal, it is necessary to answer the following open research question: Is it possible to create a test system that will be able to simulate the external world in the laboratory that driver assistance or autonomous driving systems are tested comprehensively? According to the author, there is a chance to realize such a project, but it can be time-consuming, expensive and requires a multidisciplinary team of people. The main task in such a project would be to integrate existing test systems in a way that they do not disturb each other, and they are able to stimulate all of the tested systems simultaneously.

\section{References}

[1] Systems Engineering: IEEE 1012-2016 - IEEE Standard for System, Software, and Hardware Verification and Validation, https://standards.ieee.org/standard/1012-2016.html [8.07.2021].

[2] Bücs R.L, Reyes Aristizábal J.S., Leupers R., Ascheid G.: Multi-level vehicle dynamics modeling and export for ADAS prototyping in a $3 D$ driving environment, IEEE 20th International Conference on Intelligent Transportation Systems (ITSC), Yokohama, Japan 2017.

[3] Xu F., Shen T.: A trafic-in-loop simulation system for validation of emission control strategy in diesel engine, IEEE Industrial Cyber-Physical Systems (ICPS), Sankt Petersburg, Russia 2018

[4] Yao S., Zhang J., Hu Z., Wang Y., Zhou X.: Autonomousdriving vehicle test technology based on virtual reality, The $2^{\text {nd }}$ 2018 Asian Conference on Artificial Intelligence Technology, Chongqing, China 2018

[5] Von Neumann-Cosel K., Roth E., Lehmann D., Speth J. Knoll A.: Testing of image processing algorithms on synthetic data, $4^{\text {th }}$ International Conference on Software Engineering Advances, Porto, Portugal 2009.

[6] National Instrument. Volvo Cars Improves Ride Quality Using an Open-HIL Platform and Dynamic Vehicle Simulation, https://www.ni.com/pl-pl/innovations/case-studies/19/volvocars-improves-ride-quality-using-an-open-hil-platform-anddynamic-vehicle-simulation.html [8.07.2021].

[7] Zofka M.R., Kohlhaas R., Schamm T., Zöllner J.M.: Semivirtual simulations for the evaluation of vision-based ADAS IEEE Intelligent Vehicles Symposium, Dearborn, Michigan, USA 2014.

[8] Kammerer C., Schmidt R., Hochmann G.: A Common Testing Platform for Engine and Vehicle Testbeds, ATZ Worldwide 2009.

[9] Chen C., Xiong R., Shen W.: A Lithium-Ion Battery-in-the-Loop Approach to Test and Validate Multiscale Dual H Infinity Filters for State-of-Charge and Capacity Estimation, IEEE Transactions on Power Electronics 2018.
[10] Laschinsky Y., Von Neumann-Cosel K., Gonter M., Wegwerth C., Dubitzky R., Knoll A.: Evaluation of an active safety light using virtual test drive within vehicle in the loop, IEEE International Conference on Industrial Technology, Via del Mar, Chile 2010.

[11] Hartmann M., Viehweger M., Desmet W., Stolz M., Watzenig D.: Pedestrian in the loop: An approach using virtual reality, $26^{\text {th }}$ International Conference on Information, Communication and Automation Technologies, Sarajevo, Bosnia and Herzegovina 2017.

[12] Zofka M.R., Ulbrich S., Karl D., Fleck T., Kohlhaas R., Rönnau A., Dillmann R., Zöllner M.: Trafic Participants in the Loop: A Mixed Reality-Based Interaction Testbed for the Verification and Validation of Autonomous Vehicles, IEEE Conference on Intelligent Transportation Systems, Maui, HI, USA 2018.

[13] Frost A.: Autonomous EV completes UK's longest and most complex self-driving car journey, https://www.traffictechnologytoday.com/news/autonomous-vehicles/autonomous-evcompletes-uks-longest-and-most-complex-self-driving-carjourney.html [8.07.2021].

[14] Xu S., Peng H., Song Z., Chen K., Tang Y.: Design and Test of Speed Tracking Control for the Self-Driving Lincoln MKZ Platform, IEEE Transactions on Intelligent Vehicles, 2020.

[15] Huang W.L., Wang K., Lv Y., Zhu F.H.: Autonomous vehicles testing methods review, IEEE Conference on Intelligent Transportation Systems, Rio de Janeiro, Brazil 2016.

[16] Mcity: Mcity Test Facility, https://mcity.umich.edu/our-work/ mcity-test-facility/ [28.05.2020].

[17] Zofka M.R., Essinger M., Fleck T., Kohlhaas R., Zöllner J.M.: The sleepwalker framework: Verification and validation of autonomous vehicles by mixed reality LiDAR stimulation, IEEE International Conference on Simulation, Modeling, and Programming for Autonomous Robots, Brisbane, QLD, Australia 2018.

[18] Bokc T., Maurer M., Farber G.: Validation of the Vehicle in the Loop (VIL); A milestone for the simulation of driver assistance systems, IEEE Intelligent Vehicles Symposium, Istanbul, Turkey 2007.

[19] Sieber M., Berg G., Karl I., Siedersberger K., Siegel A., Färber B.: Validation of driving behavior in the Vehicle in the Loop: Steering responses in critical situations, IEEE Conference on Intelligent Transportation Systems, The Hague, Netherlands 2013

[20] Ruger F., Nitsch V., Farber B.: Automatic Evasion Seen from the Opposing Trafic-An Investigation with the Vehicle in the Loop, IEEE Conference on Intelligent Transportation Systems, Gran Canaria, Spain 2015.

[21] Fayazi A., Vahidi A.: Vehicle-in-the-loop (VIL) verification of a smart city intersection control scheme for autonomous vehicles, $1^{\text {st }}$ Annual IEEE Conference on Control Technology and Applications, Maui, HI, USA 2017.

[22] Galko C., Rossi R., Savatier X.: Vehicle-hardware-in-the-loop system for ADAS prototyping and validation, International Conference on Embedded Computer Systems: Architectures, Modeling and Simulation, Agios Konstantinos, Greece 2014.

[23] Gietelink O., Ploeg J., De Schutter B., Verhaegen M.: Development of advanced driver assistance systems with vehicle hardware-in-the-loop simulations, "Vehicle System Dynamics" 2006, 44, 7: 569-590.

[24] Geneder S., Pfister F., Wilhelm C., Arnold A.: Development of Connected Powertrains at the Power Test Bed, ATZ Worldwide 2016.

[25] Gadringer M. E., Maier F. M., Schreiber H., Makkapati V. P., Gruber A., Vorderderfler M., Amschl D., Metzner S., Pflügl H., Bösch W., Horn M., Paulweber M.: Radar target stimulation for automotive applications, IET Radar, Sonar \& Navigation, 2018. 
[26] Förster M., Hettel R., Schyr C., Pfeffer P. E.: Lateral dynamics on the vehicle test bed - a steering force module as a validation tool for autonomous driving functions, $9^{\text {th }}$ International Munich Chassis Symposium, Munich, Germany 2018.

[27] Gadringer M., Schreiber H., Gruber A., Vorderderfler M., Amschl D., Bösch W., Metzner S., Pflügl H., Paulweber M.: Virtual reality for automotive radars, Elektrotechnik \& Informationstechnik 2018.

MICHAŁ PIETRUCH, M.Sc., Eng. Faculty of Mechanical Engineering and Robotics AGH University of Science and Technology al. A. Mickiewicza 30, 30-059 Kraków, Poland mpiet@agh.edu.pl
ANDRZEJ MEYNIEC, Ph.D., Eng., prof. Faculty of Mechanical Engineering and Robotics

AGH University of Science and Technology al. A. Mickiewicza 30, 30-059 Kraków, Poland mlyniec@agh.edu.pl

ANDRZEJ WETULA, Ph.D., Eng. Faculty of Electrical Engineering, Automatics, Computer Science and Biomedical Engineering AGH University of Science and Technology al. A. Mickiewicza 30, 30-059 Kraków, Poland wetula@agh.edu.pl

(C) 2020 Authors. This is an open access publication, which can be used, distributed and reproduced in any medium according to the Creative Commons CC-BY 4.0 License. 


\title{
Przegląd i perspektywa metod testowania wykorzystywanych do weryfikacji i walidacji ADAS, systemów aktywnego bezpieczeństwa oraz jazdy autonomicznej
}

\begin{abstract}
W ostatnich latach znacznie wzrosta liczba zaawansowanych systemów wspomagajacych kierowcę. Spowodowało to potrzebę opracowania metod testowania ich jakości $i$ niezawodności. Artykut przedstawia przeglad metod badawczych stosowanych w przemyśle motoryzacyjnym wykorzystywanych $w$ weryfikacji $i$ walidacji zaawansowanych systemów wspomagania kierowcy (ADAS), aktywnego bezpieczeństwa i systemów jazdy autonomicznej. W pierwszej części przedstawiono podejście do testów nazywanych testowaniem $w$ pętli, takich jak model $w$ pętli, oprogramowanie w pętli itd., prezentując najciekawsze implementacje. Następnie omówiono testy wykonywane na różnych terenach testowych, które maja udowodnić niezawodność i jakość systemu. Testowymi terenami moga być tory testowe, sztuczne miasta czy drogi publiczne. W ostatniej części przedstawiono walidację wykonana $w$ laboratorium $z$ wykorzystaniem metod zarówno inwazyjnych, jak i nieinwazyjnych, opartych na wirtualnych jazdach testowych, stymulatorach czujników i hamowniach podwoziowych. Ponadto zidentyfikowalismy najbardziej obiecujące podejścia do skutecznej weryfikacji i walidacji systemów ADAS, aktywnego bezpieczeństwa oraz jazdy autonomicznej. Na koniec wskazujemy potencjalne luki w tym temacie, które wymagaja dalszych badań.
\end{abstract}

Słowa kluczowe: ADAS, weryfikacja systemów aktywnego bezpieczeństwa, jazda autonomiczna, metody testowania, testowanie w pętli

\section{WPROWADZENIE}

Nowoczesne samochody są wyposażone w coraz bardziej zaawansowane systemy aktywnego bezpieczeństwa. Obecnie nie ma samochodów w pełni autonomicznych, jednak niektóre $\mathrm{z}$ nich coraz bardziej ograniczają potrzebę interakcji z kierowcą. Systemy jazdy autonomicznej są opracowywane na podstawie metod SIL (oprogramowanie w pętli) i HIL (urządzenie w pętli), natomiast testy wykonywane są manualnie na torach testowych i/lub na drogach publicznych przez kierowców testowych. Metody te są dalekie od doskonałości ze względu na brak możliwości stworzenia wielu przypadków testowych, wymaganą obecność człowieka w samochodzie podczas testów, a przede wszystkim istnienia problemu $\mathrm{z}$ wielokrotnym odtworzeniem identycznych warunków drogo- wych. Takie warunki można zreprodukować tylko w laboratorium przy użyciu specjalistycznych narzędzi. Wykonanie testów w laboratorium pozwoliłoby na testowanie samochodów w identycznych warunkach. To z kolei pozwoliłoby na porównywanie skuteczności działania systemów pomiędzy samochodami, a przede wszystkim umożliwiłoby na certyfikowanie oparte na określonych procedurach i standardach testowych. Istnieje wiele publikacji przedstawiających różne podejścia do testowania systemów aktywnego bezpieczeństwa i systemów jazdy autonomicznej - od testów laboratoryjnych po testy w ruchu drogowym. Obecnie testy w laboratorium zwane testowaniem pojazdu w pętli koncentrują się głównie na testach pojedynczego urządzenia, takiego jak radar czy lidar. Inżynierowie od jakiegoś czasu próbują stworzyć środowisko testowe, które będzie w stanie testować kilka systemów 
jednocześnie, ale niestety wciąż nie zostało ono opracowane. W związku z tym pojawia się pytanie - czy jest możliwe stworzenie środowiska testowego, które będzie w stanie symulować świat zewnętrzny w laboratorium tak, aby można było kompleksowo przetestować systemy wspomagania kierowcy lub jazdy autonomicznej? W artykule dokonano przeglądu tego tematu i podjęto próbę określenia brakujących technologii.

\section{TESTOWANIE W PĘTLI}

Testowanie w pętli (X w pętli) to konwencja nazewnictwa, w której $\mathrm{X}$ oznacza obiekt poddawany testom. Ponieważ testowanie nie jest czynnością wykonywaną jednokrotnie, ale czynnością cykliczną, nazywane jest testowaniem w pętli. W branży motoryzacyjnej można w pętli testować różne rzeczy, które zostaną tutaj przybliżone. Podejścia te są uporządkowane chronologicznie zgodnie $\mathrm{z}$ harmonogramem rozwoju testowanego systemu, jak pokazano na rysunku 1. Należy jednak pamiętać, że nie wszystkie kroki muszą zostać wykonane, gdyż to zależy od specyfiki i złożoności systemu. Warto również zauważyć pewną różnicę pomiędzy weryfikacją i walidacją. Weryfikacja jest to sprawdzenie, czy system spełnia wcześniej zdefiniowane wymagania, standardy i normy, natomiast walidacja dostarcza dowodów, że system spełnia swoją funkcję w prawdziwym zastosowaniu, w docelowym środowisku [1].

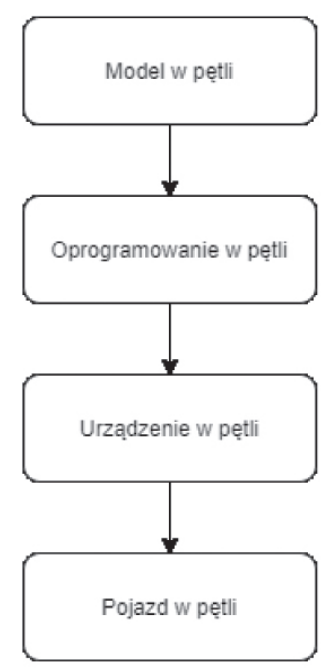

Rys. 1. Etapy tworzenia systemu

\subsection{Model-in-the-loop (MIL)}

Pierwszym krokiem podczas wytwarzania systemu jest stworzenie modelu w pętli (MIL), gdzie projekto- wany system ma postać modelu stworzonego w narzędziu modelującym, np. w MATLAB-Simulink. Z podstawowych komponentów tworzony jest ogólny, wysokopoziomowy model działania systemu. Dzięki temu możemy zaprojektować system bez wchodzenia w szczegóły implementacyjne, które zależą od języka programowania. Dodatkowo, mając taki model, możemy automatycznie wygenerować kod w określonym języku programowania za pomocą np. Simulink Coder lub Target Link [2], dzięki czemu unikamy ręcznego pisania kodu [3], jak pokazano na rysunku 2. Testowanie stworzonego modelu obejmuje dostarczenie zestawu symulowanych sygnałów jako wejście do modelu i sprawdzenie jego odpowiedzi na te sygnały.

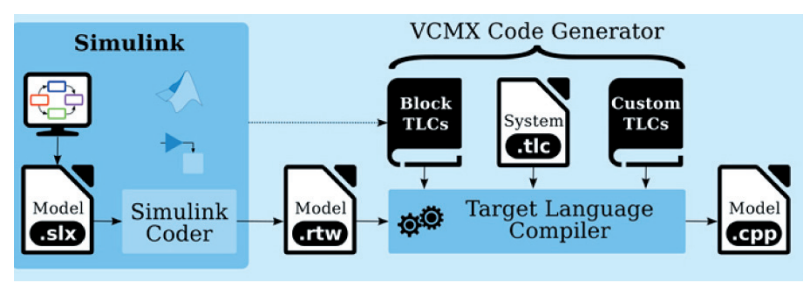

Rys. 2. Proces generowania kodu z wykorzystaniem Simulink [2]

\subsection{Oprogramowanie w pętli (SIL)}

Kolejnym krokiem jest oprogramowanie w pętli (SIL), gdzie przedmiotem testów nie jest już model blokowy, ale kod w określonym języku programowania, np. C++. Możemy następnie przetestować ten kod, dostarczając do jego wejść odpowiednie sztuczne lub pozyskane dane. Dzięki temu możnazweryfikować poprawność zaimplementowanych algorytmów w określonym języku programowania niezależnie od docelowego sprzętu, np. z kodem uruchomionym na komputerze PC [4]. Takie podejście niesie za sobą pewne ryzyko. Przede wszystkim, jeśli program komputerowy jest kompilowany innym kompilatorem od docelowego, to kod maszynowy może się nieco różnić. Podczas wykonywania program może zachowywać się nieco inaczej, więc nie ma $100 \%$ pewności, że program zadziała dokładnie tak samo na docelowym sprzęcie.

\subsection{Urządzenie w pętli (HIL)}

Po zakończeniu testów SIL przeprowadzane są testy urządzenia w pętli (HIL), gdzie oprogramowanie jest już testowane na docelowym sprzęcie, ale nadal jeszcze nie w docelowym środowisku. Oznacza to, że wszystkie inne współpracujące urządzenia elektroniczne muszą zostać sztucznie zasymulowane, ale 
z funkcjonalnego punktu widzenia testowanego urządzenia nie ma większej różnicy, czy znajduje się ono w środowisku rzeczywistym, czy symulowanym. To chyba najczęstszy rodzaj testów wykonywanych w branży motoryzacyjnej, ponieważ zwykle producent projektowanego urządzenia odpowiada tylko za jedno z nich i nie ma dostępu do innych współpracujących urządzeń. Przykładem HIL może być urządzenie, które jest odpowiedzialne za rozpoznawanie linii rozdzielających pasy na drodze, które jest testowane w symulowanym środowisku [5] czy HIL pokazany na rysunku 3. Główną wadą tej metody jest to, że urządzenie nie jest testowane w rzeczywistym środowisku z innymi rzeczywistymi urządzeniami, z docelowymi zasilaczami itp., dlatego istnieje ryzyko, że w rzeczywistym środowisku urządzenie nie będzie działać do końca poprawnie.

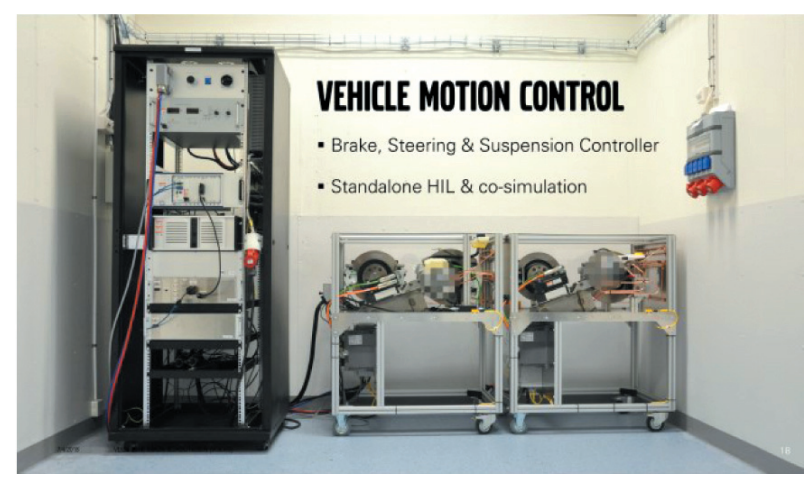

Rys. 3. HIL system testujący kontrolery hamowania, sterowania oraz zawieszenia [6]

\subsection{Pojazd w pętli (VIL)}

Ostatnim etapem testów jest przetestowanie samochodu w całości. Najczęściej ustawia się go na hamowni podwoziowej, która przykładając odpowiedni moment obrotowy do kół, symuluje jazdę pod wzniesienie oraz inne opory ruchu. Dodatkowo różne czujniki samochodu są stymulowane za pomocą różnego rodzaju urządzeń współpracujących z symulatorami jazdy odpowiedzialnymi za wirtualne jazdy testowe. $\mathrm{W}$ tej metodzie badawczej często można spotkać się $\mathrm{z}$ terminami, takimi jak testowanie w pętli otwartej oraz zamkniętej, które tutaj pokrótce omówię.

\subsubsection{Testowanie w pętli otwartej}

Testowanie w pętli otwartej polega na tym, że testowane urządzenie czy system jest stymulowany z zewnątrz, ale jego odpowiedź nie jest zwracana do symulatora. $\mathrm{Z}$ tego powodu $\mathrm{w}$ symulacji nie pojawia się informacja o reakcji samochodu na wygenerowany sygnał stymulujący. Przykładem testowania w otwartej pętli może być urządzenie, które odpowiada za detekcję innych samochodów podczas jazdy [7]. Pierwszym krokiem było nagranie filmu podczas prawdziwej jazdy testowej, następnie identyczna jazda testowa została przeprowadzona w symulatorze, a na koniec samochody z wirtualnej jazdy testowej zostały wyekstrahowane i nałożone na nagrany, rzeczywisty film, co pokazano na rysunku 4. Końcowy test polegał na przesłaniu tego filmu z dodanymi samochodami do kamery i przeanalizowaniu, czy urządzenie wykryło inne pojazdy na drodze. W takich warunkach nie jest możliwe przetestowanie działania systemu aktywnego bezpieczeństwa, gdyż nagrane wideo nie reaguje i nie odzwierciedla odpowiedzi systemu.

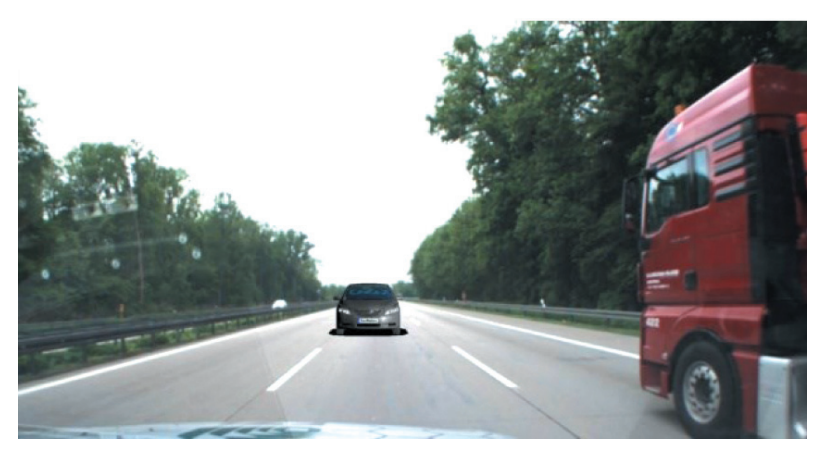

Rys. 4. Kadr z filmu z rzeczywistej jazdy testowej rozszerzony o samochody wirtualne [7]

\subsubsection{Testowanie w pętli zamkniętej}

Testowanie w pętli zamkniętej polega na tym, że odpowiedź testowanego systemu jest zwracana do symulatora. Dzięki temu w symulacji widoczna jest reakcja samochodu. Testowanie w pętli zamkniętej zapewnia interakcję pomiędzy symulowanym światem a rzeczywistym samochodem, ale jest znacznie bardziej wymagająca w implementacji niż metoda otwartej pętli.

\subsection{Inne metody}

Oprócz metod standardowych opisanych powyżej istnieje wiele innych, bardziej szczegółowych metod, takich jak silnik w pętli (EIL) czy bateria w pętli (BIL), w których silnik spalinowy [8] lub baterie sa poddawane testom w pętli [9]. Czasami również człowiek jest poddawany testom w celu oceny jego zachowania w określonych sytuacjach lub oceny jego współpracy z systemami bezpieczeństwa. 


\subsubsection{Kierowca w pętli (DIL)}

Oprócz testowania wyprodukowanego systemu można również przetestować zachowanie kierowcy podczas jazdy samochodem (rys. 5). Dzięki temu można uzyskać informacje o zachowaniu kierowcy w różnych sytuacjach i tym samym lepiej zaprojektować system w samochodzie. Ponadto można ocenić współpracę kierowcy np. z aktywnymi systemami bezpieczeństwa w celu sprawdzenia, czy dodatkowe systemy bezpieczeństwa poprawiają, czy pogarszają reakcję kierowcy. Przykładem może być badanie czasu reakcji kierowcy podczas hamowania przy współpracy z inteligentnymi lampami [10]. Oczywiście kierowcę również można przetestować w mniej realnym środowisku, np. podczas całkowicie wirtualnej jazdy testowej, niemniej jednak najdokładniejszą metodą jest sprawdzenie zachowania kierowcy w prawdziwym pojeździe podczas prawdziwej jazdy testowej. Takie podejście daje najdokładniejsze wyniki oraz pewność, że zaprojektowany system bezpieczeństwa poprawia lub pogarsza bezpieczeństwo kierowcy.

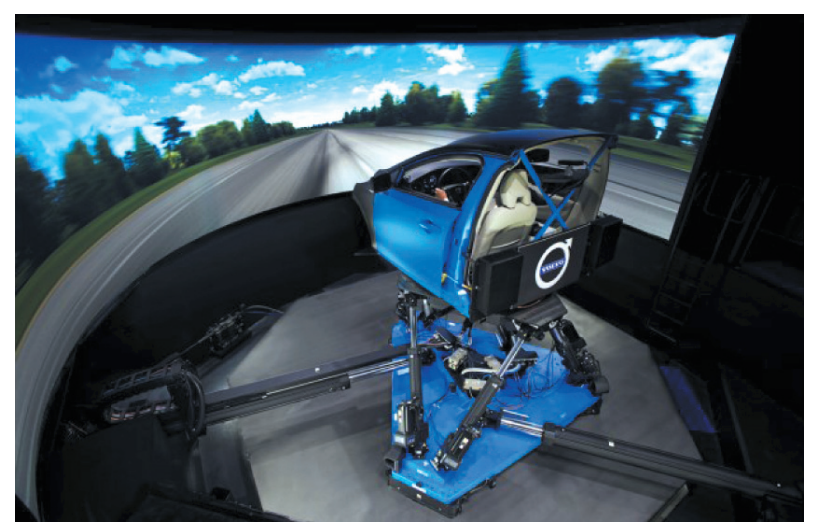

Rys. 5. Symulator dynamicznej jazdy marki Volvo [6]

\subsubsection{Pieszy w pętli (PIL)}

Zachowanie pieszych można badać podobnie jak zachowanie kierowcy. Obserwując pieszych w różnych sytuacjach, można ocenić, jak wchodzą w interakcję $\mathrm{z}$ samochodem. Ciekawy przykład podano w publikacji [11], w której obserwuje się zachowanie kilku osób podczas niebezpiecznego zdarzenia z samochodem autonomicznym. Piesi podczas testu mają na głowach gogle VR, w których wyświetlana jest wirtualna jazda testowa. Podobne testy przeprowadzono z jednym przechodniem, którego zadaniem było wejście w odpowiednim momencie na przejście dla pieszych w celu sprawdzenia, czy algorytm awaryjnego hamowania pojazdu zadziała prawidłowo [12], co ukazano na rysunkach 6 i 7 .

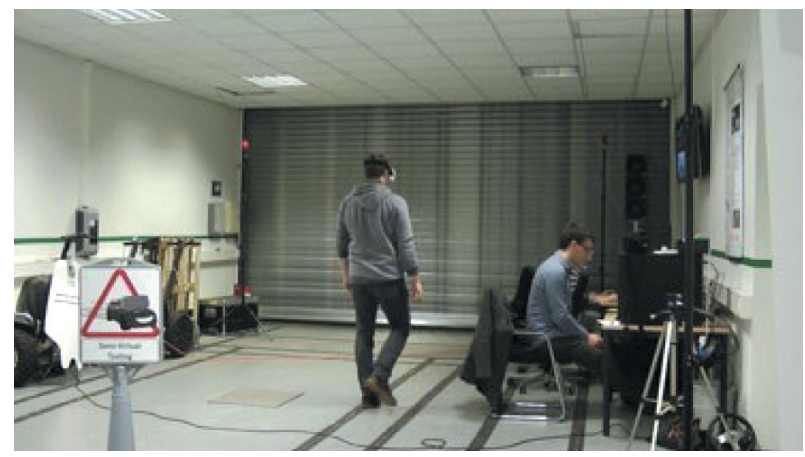

Rys. 6. Pieszy z goglami VR [12]

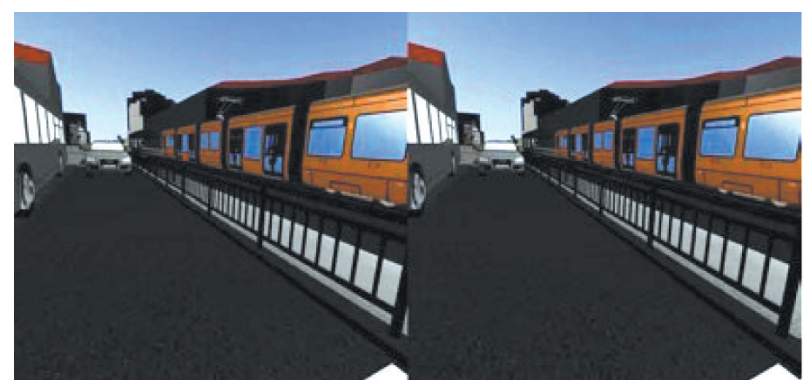

Rys. 7. Obraz widziany przez pieszego z rysunku 6 [12]

\section{METODY TESTOWANIA POJAZDU}

Do tej pory zaprezentowano podejście testowania w pętli. Ostatnim krokiem jest przeprowadzenie testów pojazdu w rzeczywistych warunkach. Istnieją trzy główne rodzaje testów: ruch drogowy, sztuczne miasta i tory testowe.

\subsection{Testowanie w ruchu drogowym}

Jazdy testowe w ruchu drogowym to najpopularniejsza metoda testowania jazdy autonomicznej i systemów aktywnego bezpieczeństwa. Oprócz oczywistych zalet wynikających z jazdy w naturalnym, docelowym środowisku ma również wiele wad. Pierwszą wadą jest mała powtarzalność warunków testowych, które są w zasadzie nieodtwarzalne. Po drugie, samochód musi być w pełni sprawny, aby wykonać testy, więc testy te jedynie moga być przeprowadzone pod koniec tworzenia produktu, tym samym wydłużając całkowity czas produkcji. Po trzecie, jazda testowa może spowodować zagrożenie dla innych uczestników ruchu oraz samego kierowcy, dlatego unika się testowania niedojrzałych systemów. Po czwarte, testowanie na drogach publicznych jest niewygodne i czasochłonne, ponieważ każda modyfikacja urządzenia lub oprogramowania wymaga powrotu do siedziby firmy. Niestety w coraz większej liczbie 
krajów zakazuje się testowania samochodów autonomicznych w ruchu drogowym z powodu wypadków, jednak skutkuje to rozwojem nowych, alternatywnych metod testowania. Przykład testu w ruchu ulicznym został pokazany na rysunku 8 .

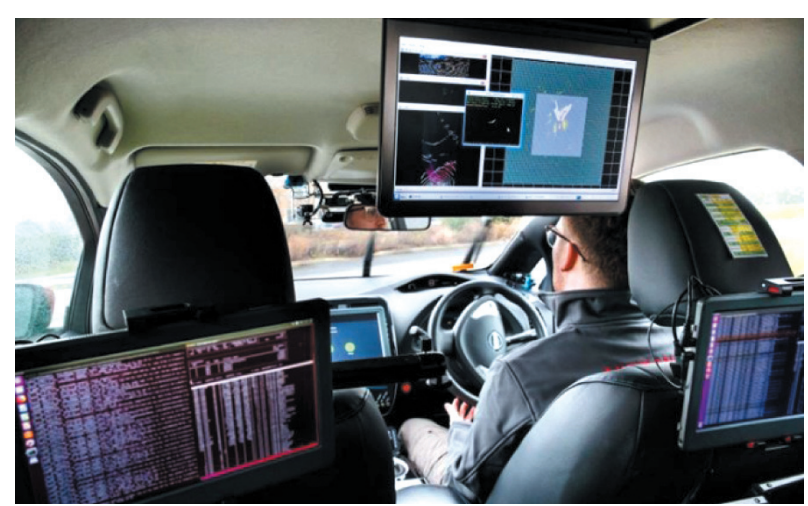

Rys. 8. Testowanie w ruchu ulicznym [13]

\subsection{Testowanie na terenach zamkniętych}

Oprócz testów w ruchu drogowym wykonuje się testy na terenach zamkniętych specjalnie przystosowanych do testów.

\subsubsection{Sztuczne miasta}

Alternatywą może być testowanie samochodów w sztucznych warunkach. Może to być na przykład sztuczne miasto, które zostało zbudowane specjalnie do celów testowych. Takie miasta istnieją m.in. w Korei Południowej - K-city [14] czy w Stanach Zjednoczonych - Mcity [15]. Na rysunku 9 przedstawiono mapę takiego miasta.

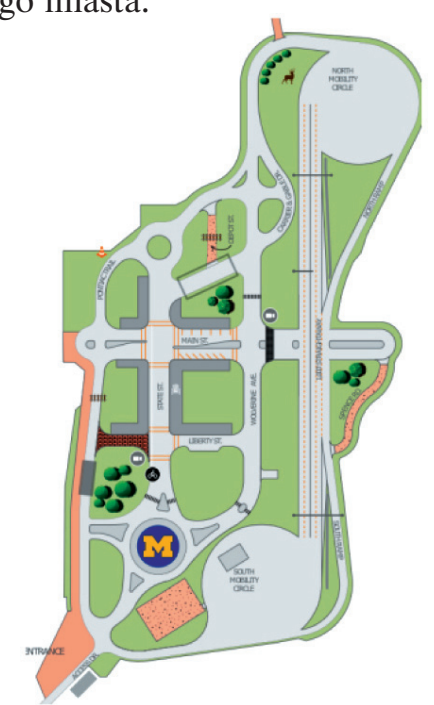

Rys. 9. Mapa Mcity [5]

Mcity składa się z czterdziestu fasad budynków, $\mathrm{z}$ tunelu, mostu, czteropasmowej autostrady, a nawet mechanicznych pieszych, którzy mogą wchodzić na przejście dla pieszych. Ponadto jest wyposażone w standardowe oznakowanie drogowe oraz sygnalizację świetlną [15]. Fragment Mcity pokazano na rysun$\mathrm{ku} 10$. Testowanie w takich warunkach ma wiele zalet, np. możliwość testowania w warunkach, które nie zagrażają innym użytkownikom drogi. Ponadto warunki testowe są w większości odtwarzalne z wyjątkiem warunków pogodowych. Istotną zaletą jest możliwość dowolnej konfiguracji otoczenia, na przykład przez zmianę znaków czy sygnalizacji świetlnej. Pomimo tych zalet metoda ta ma jednak pewne wady, np. nadal istnieje pewne zagrożenie dla kierowcy podczas wykonywania testów. Poza tym budowa takiego miasta jest bardzo kosztowna i długotrwała, a sam samochód nadal musi być $\mathrm{w}$ pełni funkcjonalny.

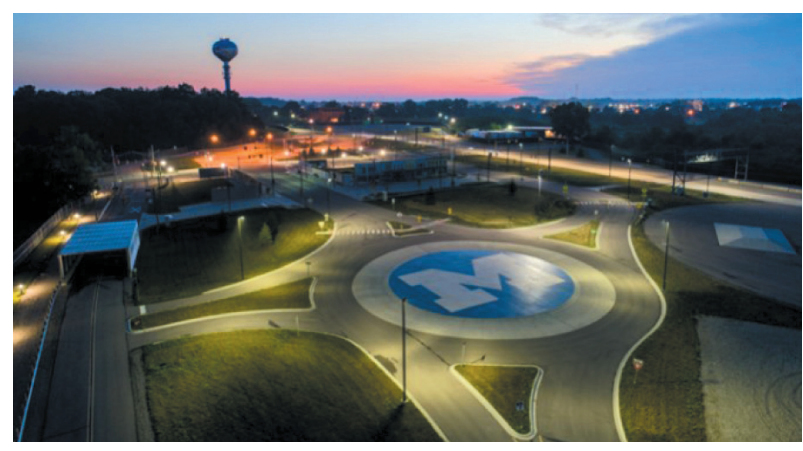

Rys. 10. Mcity [16]

\subsubsection{Tory testowe}

Tańszą alternatywą jest testowanie na torach testowych lub wszelkiego rodzaju pustych placach czy zamkniętych drogach. Zwykle na torze znajdują się pojedyncze przeszkody, które pozwalają na walidację pojedynczego systemu aktywnego bezpieczeństwa, np. hamowania awaryjnego. Przykład testowania na placu testowym został pokazany na rysunku 11 . Ten rodzaj testowania jest prawdopodobnie najpopularniejszy, ponieważ jest najtańszy i najszybszy do zrealizowania. Często jest to faza początkowa przed testowaniem w ruchu drogowym.

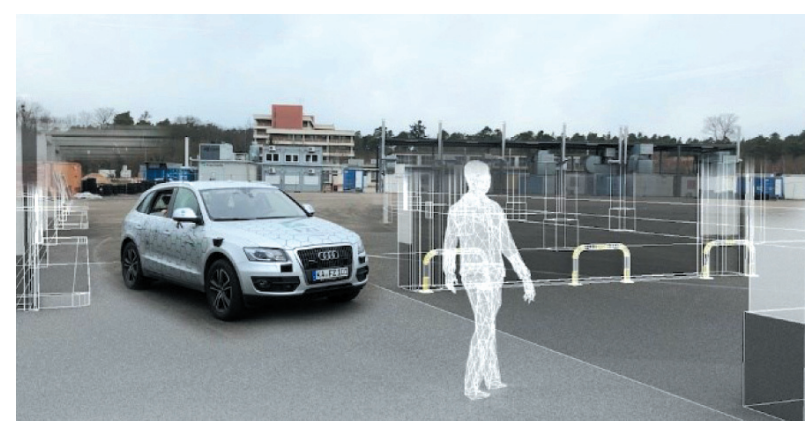

Rys. 11. Samochód testowany na torze testowym w rozszerzonej rzeczywistości [17] 


\subsubsection{Testy półwirtualne}

Powszechną praktyką jest również łączenie wirtualnej jazdy testowej z rzeczywistą jazdą testową. $\mathrm{Na}$ początku w symulacji odwzorowuje się prawdziwy tor. Następnie podczas rzeczywistego przejazdu samochód testowy wyposażony w bardzo dokładny różnicowy GPS (DGPS) przesyła swoją lokalizację do symulatora, który następnie odsyła dane w odpowiednim formacie, np. do radaru. Te dane są przesyłane bezpośrednio do sterownika radaru z pominięciem samego czujnika radarowego i wyzwalany jest system aktywnego bezpieczeństwa [18, 19]. Dzięki temu test odbywa się na prawdziwym torze, na którym nie ma innych uczestników ruchu drogowego, natomiast z perspektywy samochodu jedzie on po tym samym torze jednocześnie $\mathrm{z}$ innymi samochodami. Również często w takich przejazdach mieszanych kierowca wyposażony jest w gogle, w których rzeczywistość jest rozszerzona o elementy generowane przez symulator. Dzięki takiemu podejściu kierowca unika choroby lokomocyjnej, a ponadto jest świadomy czynników powodujących manewry samochodu.

Innym podejściem do testów półwirtualnych jest jazda po pustym torze, na którym kierowca wyposażony jest w gogle VR wyświetlające całkowicie wirtualną jazdę testową, co pokazano na rysunku 12 . Zaletą tego podejścia jest to, że kierowca doświadcza wszystkich sił podczas wirtualnej jazdy próbnej [20].

Testy półwirtualne można również zastosować podczas testowania kontrolera zarządzania sygnalizacją świetlną. Kontroler przydziela czas, w którym każdy samochód może przejechać przez skrzyżowanie. Ponieważ testowany samochód nie był wyposażony w układy wykonawcze będące w stanie sterować samochodem, był on prowadzony przez kierowcę wykonującego polecenia sterownika, które były wysyłane do specjalnej aplikacji na smartfonie [21].

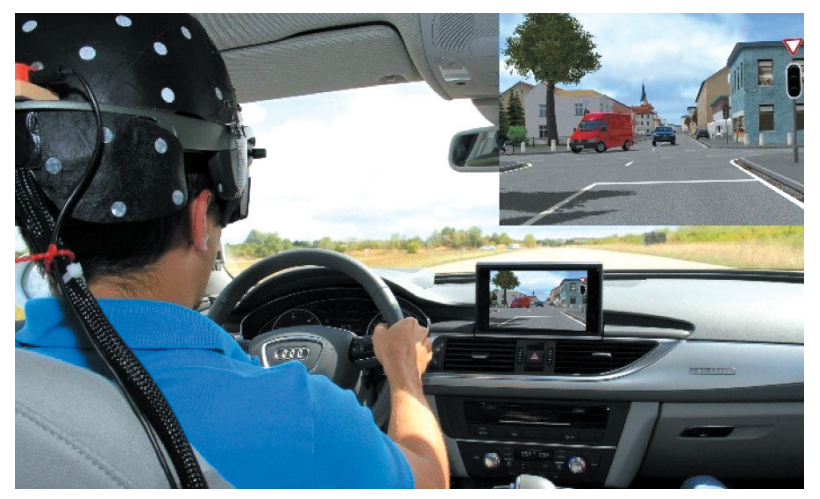

Rys. 12. Rzeczywista jazda testowa rozszerzona o wirtualne samochody [20]
Testy półwirtualne często wymagają obecności kierowcy w samochodzie, co może być niebezpieczne, zwłaszcza gdy pojazd jest prototypem. Ryzyka tego można uniknąć, zastępując kierowcę układami wykonawczymi, którymi następnie można sterować zdalnie.

\subsection{Testy w laboratorium}

Jeśli chodzi o testowanie pojazdu w pętli w warunkach laboratoryjnych, problemem jest symulacja świata zewnętrznego i stymulowanie czujników samochodu, aby można było przetestować konkretną funkcjonalność. Można to zrobić na kilka sposobów, które zostaną przedstawione poniżej.

\subsubsection{Metody inwazyjne}

W metodach inwazyjnych zachodzi ingerencja w konstrukcję samochodu. Najbardziej inwazyjną metodą jest odłączenie zarówno czujnika, jak i sterownika i wprowadzenie odpowiednich danych bezpośrednio do magistrali komunikacyjnej [22]. $\mathrm{Na}$ przykład sterownik radaru może zostać całkowicie odłączony, a na magistrale komunikacyjną są wstrzykiwane ramki zawierające określone wartości. Dzięki temu możemy obserwować reakcję pojazdu na te dane. Metoda ta jest niewygodna i w zasadzie rzadko stosowana, ponieważ wymaga sporej ingerencji w konstrukcję samochodu oraz dogłębnej znajomości przesyłanych struktur danych na magistrali. $\mathrm{Z}$ tego powodu metoda ta jest wykorzystywana przez producentów samochodów, którzy posiadają wszelkiego rodzaju dokumentację potrzebną do wykonania takich testów.

Mniej inwazyjnym sposobem jest pozostawienie podłączonego sterownika, ale odłączenie samego czujnika, a następnie wysłanie sygnałów elektrycznych do sterownika zgodnie ze specyfikacją czujnika. Ze względu na znacznie łatwiejszy dostęp do dokumentacji czujnika niż do dokumentacji opisującej komunikację wewnętrzną samochodu metoda ta jest już stosowana sporadycznie.

\subsubsection{Metody nieinwazyjne}

Istnieje też kilka metod, które nie ingerują w konstrukcję samochodu. Pierwsza z nich polega na ustawieniu fizycznych obiektów przed samochodem w celu uruchomienia testowanych systemów, np. systemu awaryjnego hamowania. 
Do tego celu można na przykład wykorzystać dużą halę, na której samochód jest ustawiony na hamowni podwoziowej, a pozostałe sztuczne samochody poruszają się ruchem względnym wobec tego samochodu [23], jak pokazano na rysunku 13. Niestety to rozwiązanie ma wiele wad. Jest bardzo kosztowne, ponieważ trzeba zbudować sztuczne samochody lub inne obiekty, które będą wchodzić $\mathrm{w}$ interakcję $\mathrm{z}$ testowanym samochodem, oraz konieczne jest również posiadanie dużego pomieszczenia o długości około $100 \mathrm{~m}$ [23]. Ponadto takie przedsięwzięcie niesie pewne niebezpieczeństwo dla otoczenia, gdyż pojazdy są w permanentnym ruchu.

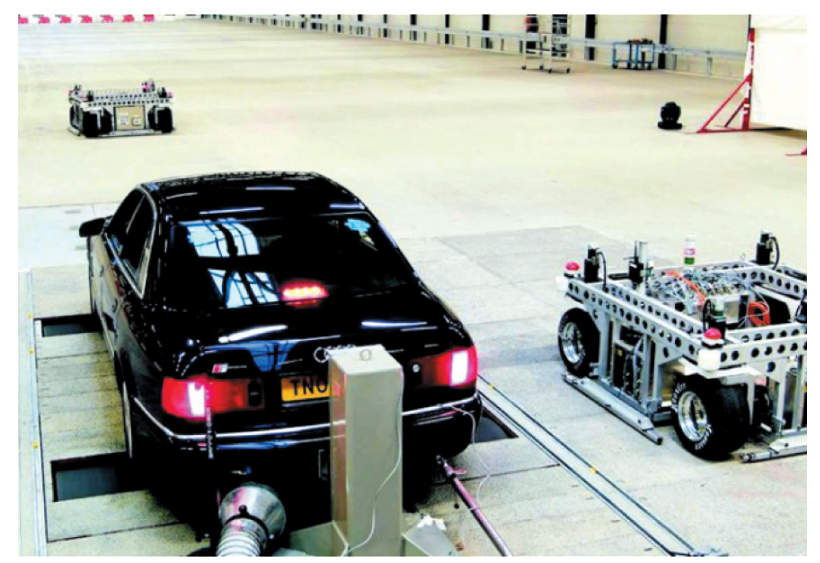

Rys. 13. Testowany pojazd na hamowni z sztucznymi samochodami [23]

Kolejnym rozwiązaniem jest stymulacja czujników samochodu za pomocą przeznaczonych do tego urządzeń - stymulatorów. Podejście to jest powszechnie stosowane podczas testowania systemów aktywne- go bezpieczeństwa lub zaawansowanych systemów wspomagania kierowców - ADAS. System testowy tego typu składa się z kilku elementów. Obejmuje symulator jazdy będący programem komputerowym wykonującym wirtualne jazdy testowe. W takim narzędziu można tworzyć specyficzne drogi, określać liczbę pasów, poziom nachylenia drogi, wstawiać drzewa i innych uczestników ruchu, takich jak samochody, piesi itp. [24]. Rzeczywisty samochód jest odwzorowywany $\mathrm{w}$ symulatorze, a w literaturze jest określany jako pojazd EGO. Symulator ma wbudowane modele czujników, takich jak radar, lidar itp., dzięki czemu dostarcza sygnały w formacie używanym w badanym systemie, które następnie przesyłane są bezprzewodowo do odpowiednich czujników w samochodzie za pomocą specjalistycznego sprzętu. Badany samochód reaguje na otrzymane dane, zmieniając trajektorie ruchu lub aktywując odpowiedni system aktywnego bezpieczeństwa. Odpowiedź tego systemu jest mierzona, a wartości fizyczne są przesyłane z powrotem do symulatora. Na podstawie tych danych pojazd EGO odzwierciedla zachowanie badanego pojazdu podczas wirtualnej jazdy testowej. Przykładem tego rozwiązania jest projekt Driving Cube [25, 26], w którym samochód został umieszczony na hamowni podwoziowej, a z przodu samochodu umieszczono specjalne urządzenia do bezprzewodowego stymulowania czujników, jak pokazano na rysunku 14. Specjalistyczny program komputerowy wykonał wirtualną jazdę testową i wygenerował dane dla stymulatorów oraz hamowni podwoziowej.

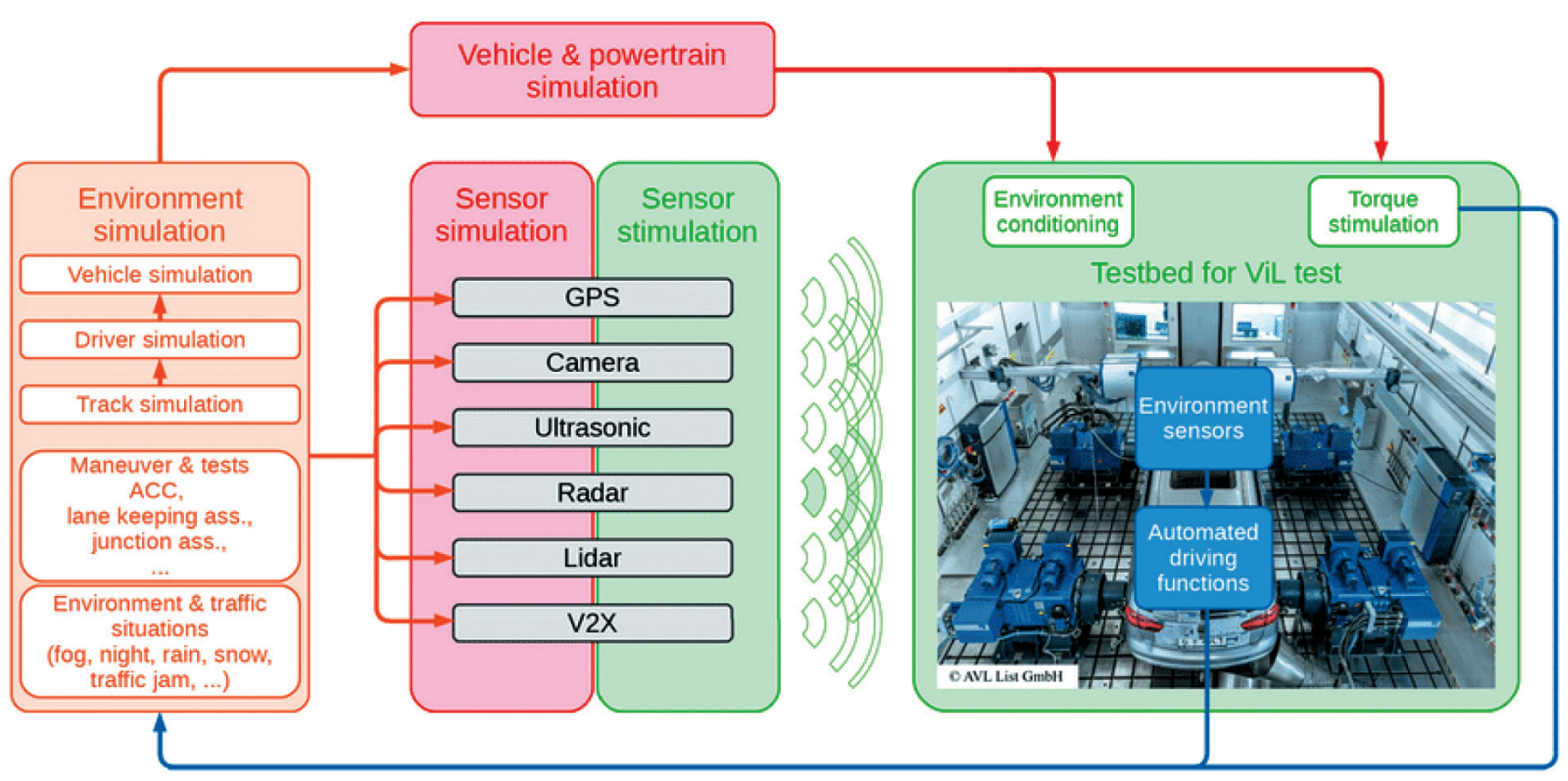

Rys. 14. Driving Cube - stanowisko testowe do kompleksowego testowania jazdy autonomicznej [27] 


\section{PODSUMOWANIE}

Istnieje kilka sposobów weryfikacji i walidacji zaawansowanych systemów wspomagania kierowcy ADAS, systemów aktywnego bezpieczeństwa i jazdy autonomicznej - od testów w laboratorium do testów w ruchu drogowym. Obecnie badania laboratoryjne są szeroko stosowane i stale rozwijane, jednak ze względu na koszty mogą sobie na to pozwolić tylko największe koncerny samochodowe i ośrodki badawczo-rozwojowe. Niestety nie ma systemu testowego VIL, który byłby w stanie stymulować jednocześnie wszystkie systemy używane do jazdy autonomicznej. $\mathrm{Na}$ podstawie przeprowadzonego przeglądu stwierdzono, że istnieją systemy, które testują jedynie pojedyncze systemy. Driving Cube jest rzadkim przykładem, w którym radar i kamera są testowane jednocześnie. W takim systemie brakuje przede wszystkim stymulacji lidaru oraz stymulatora GPS, które są kluczowymi systemami wykorzystywanymi podczas jazdy autonomicznej. Pomimo ciągle rozwijanych metod do osiągnięcia opisanego powyżej celu niezbędna jest odpowiedź na pytanie: Czy możliwe jest stworzenie środowiska testowego, które będzie w stanie symulować w laboratorium świat zewnętrzny, w którym systemy wspomagania kierowcy oraz autonomicznej jazdy będą kompleksowo testowane? Zdaniem autorów jest szansa na zrealizowanie takiego projektu, ale będzie to czasochłonne, kosztowne i wymagające multidyscyplinarnego zespołu ludzi. Głównym zadaniem w takim projekcie byłoby zintegrowanie istniejących systemów testowych w taki sposób, aby nie przeszkadzały i nie zakłócały się nawzajem i były w stanie stymulować wszystkie testowane systemy jednocześnie.

\section{Literatura}

[1] Systems Engineering: IEEE 1012-2016 - IEEE Standard for System, Software, and Hardware Verification and Validation, https://standards.ieee.org/standard/1012 2016.html [8.07.2021].

[2] Bücs R.L., Reyes Aristizábal J.S., Leupers R., Ascheid G.: Multi-level vehicle dynamics modeling and export for $A D A S$ prototyping in a $3 D$ driving environment, IEEE 20th International Conference on Intelligent Transportation Systems (ITSC), Yokohama, Japan 2017.

[3] Xu F., Shen T.: A trafic-in-loop simulation system for validation of emission control strategy in diesel engine, IEEE Industrial Cyber-Physical Systems (ICPS), Sankt Petersburg, Russia 2018.

[4] Yao S., Zhang J., Hu Z., Wang Y., Zhou X.: Autonomousdriving vehicle test technology based on virtual reality, The $2^{\text {nd }}$ 2018 Asian Conference on Artificial Intelligence Technology, Chongqing, China 2018.
[5] Von Neumann-Cosel K., Roth E., Lehmann D., Speth J., Knoll A.: Testing of image processing algorithms on synthetic data, $4^{\text {th }}$ International Conference on Software Engineering Advances, Porto, Portugal 2009.

[6] National Instrument. Volvo Cars Improves Ride Quality Using an Open-HIL Platform and Dynamic Vehicle Simulation, https://www.ni.com/pl-pl/innovations/case-studies/19/volvocars-improves-ride-quality-using-an-open-hil-platform-anddynamic-vehicle-simulation.html [8.07.2021].

[7] Zofka M.R., Kohlhaas R., Schamm T., Zöllner J.M.: Semivirtual simulations for the evaluation of vision-based $A D A S$, IEEE Intelligent Vehicles Symposium, Dearborn, Michigan, USA 2014.

[8] Kammerer C., Schmidt R., Hochmann G.: A Common Testing Platform for Engine and Vehicle Testbeds, ATZ Worldwide 2009.

[9] Chen C., Xiong R., Shen W.: A Lithium-Ion Battery-in-the-Loop Approach to Test and Validate Multiscale Dual H Infinity Filters for State-of-Charge and Capacity Estimation, IEEE Transactions on Power Electronics 2018.

[10] Laschinsky Y., Von Neumann-Cosel K., Gonter M., Wegwerth C., Dubitzky R., Knoll A.: Evaluation of an active safety light using virtual test drive within vehicle in the loop, IEEE International Conference on Industrial Technology, Via del Mar, Chile 2010.

[11] Hartmann M., Viehweger M., Desmet W., Stolz M., Watzenig D.: Pedestrian in the loop: An approach using virtual reality, $26^{\text {th }}$ International Conference on Information, Communication and Automation Technologies, Sarajevo, Bosnia and Herzegovina 2017.

[12] Zofka M.R., Ulbrich S., Karl D., Fleck T., Kohlhaas R., Rönnau A., Dillmann R., Zöllner M.: Trafic Participants in the Loop: A Mixed Reality-Based Interaction Testbed for the Verification and Validation of Autonomous Vehicles, IEEE Conference on Intelligent Transportation Systems, Maui, HI, USA 2018

[13] Frost A.: Autonomous EV completes UK's longest and most complex self-driving car journey, https://www.traffictechnologytoday.com/news/autonomous-vehicles/autonomous-evcompletes-uks-longest-and-most-complex-self-driving-carjourney.html [8.07.2021].

[14] Xu S., Peng H., Song Z., Chen K., Tang Y.: Design and Test of Speed Tracking Control for the Self-Driving Lincoln MKZ Platform, IEEE Transactions on Intelligent Vehicles, 2020.

[15] Huang W.L., Wang K., Lv Y., Zhu F.H.: Autonomous vehicles testing methods review, IEEE Conference on Intelligent Transportation Systems, Rio de Janeiro, Brazil 2016.

[16] Mcity: Mcity Test Facility, https://mcity.umich.edu/our-work/ mcity-test-facility/ [28.05.2020].

[17] Zofka M.R., Essinger M., Fleck T., Kohlhaas R., Zöllner J.M.: The sleepwalker framework: Verification and validation of autonomous vehicles by mixed reality LiDAR stimulation, IEEE International Conference on Simulation, Modeling, and Programming for Autonomous Robots, Brisbane, QLD, Australia 2018.

[18] Bokc T., Maurer M., Farber G.: Validation of the Vehicle in the Loop (VIL); A milestone for the simulation of driver assistance systems, IEEE Intelligent Vehicles Symposium, Istanbul, Turkey 2007.

[19] Sieber M., Berg G., Karl I., Siedersberger K., Siegel A., Färber B.: Validation of driving behavior in the Vehicle in the Loop: Steering responses in critical situations, IEEE Conference on Intelligent Transportation Systems, The Hague, Netherlands 2013.

[20] Ruger F., Nitsch V., Farber B.: Automatic Evasion Seen from the Opposing Trafic-An Investigation with the Vehicle in the Loop, IEEE Conference on Intelligent Transportation Systems, Gran Canaria, Spain 2015. 
[21] Fayazi A., Vahidi A.: Vehicle-in-the-loop (VIL) verification of a smart city intersection control scheme for autonomous vehicles, $1^{\text {st }}$ Annual IEEE Conference on Control Technology and Applications, Maui, HI, USA 2017.

[22] Galko C., Rossi R., Savatier X.: Vehicle-hardware-in-the-loop system for $A D A S$ prototyping and validation, International Conference on Embedded Computer Systems: Architectures, Modeling and Simulation, Agios Konstantinos, Greece 2014.

[23] Gietelink O., Ploeg J., De Schutter B., Verhaegen M.: Development of advanced driver assistance systems with vehicle hardware-in-the-loop simulations, „Vehicle System Dynamics" 2006, 44, 7: 569-590.

[24] Geneder S., Pfister F., Wilhelm C., Arnold A.: Development of Connected Powertrains at the Power Test Bed, ATZ Worldwide 2016.

[25] Gadringer M. E., Maier F. M., Schreiber H., Makkapati V. P., Gruber A., Vorderderfler M., Amschl D., Metzner S., Pflügl H., Bösch W., Horn M., Paulweber M.: Radar target stimulation for automotive applications, IET Radar, Sonar \& Navigation, 2018.

[26] Förster M., Hettel R., Schyr C., Pfeffer P. E.: Lateral dynamics on the vehicle test bed - a steering force module as a validation tool for autonomous driving functions, $9^{\text {th }}$ International Munich Chassis Symposium, Munich, Germany 2018.

[27] Gadringer M., Schreiber H., Gruber A., Vorderderfler M., Amschl D., Bösch W., Metzner S., Pflügl H., Paulweber M.: Virtual reality for automotive radars, Elektrotechnik \& Informationstechnik 2018. mgr inz. MICHAŁ PIETRUCH

Wydziat Inżynierii Mechanicznej i Robotyki

AGH Akademia Górniczo-Hutnicza

im. Stanistawa Staszica w Krakowie

al. A. Mickiewicza 30, 30-059 Kraków

mpiet@agh.edu.pl

dr hab. inż. ANDRZEJ MŁYNIEC

Wydział Inżynierii Mechanicznej i Robotyki AGH Akademia Górniczo-Hutnicza im. Stanistawa Staszica w Krakowie al. A. Mickiewicza 30, 30-059 Kraków mlyniec@agh.edu.pl

dr inż. ANDRZEJ WETULA

Wydziat Elektrotechniki, Automatyki, Informatyki i Inżynierii Biomedycznej AGH Akademia Górniczo-Hutnicza im. Stanistawa Staszica w Krakowie al. A. Mickiewicza 30, 30-059 Kraków wetula@agh.edu.pl

(C) 2020 Autorzy. Jest to publikacja ogólnodostępna, którą można wykorzystywać, rozpowszechniać i kopiować w dowolnej formie zgodnie z licencją Creative Commons CC-BY 4.0. 